\title{
Motor Discoordination Results from Combined Gene Disruption of the NMDA Receptor NR2A and NR2C Subunits, But Not from Single Disruption of the NR2A or NR2C Subunit
}

\author{
Hiroshi Kadotani, ${ }^{1}$ Tomoo Hirano, ${ }^{2}$ Miwako Masugi, ${ }^{1}$ Kenji Nakamura,, ${ }^{3}$ Kazuki Nakao, ${ }^{3}$ Motoya Katsuki, ${ }^{3}$ and \\ Shigetada Nakanishi ${ }^{1}$
}

Departments of ${ }^{1}$ Biological Sciences and 2 Physiology, Kyoto University Faculty of Medicine, Kyoto 606, Japan, and

3/nstitute of Medical Science, University of Tokyo, Tokyo 108, Japan

NMDA receptors consist of two distinct classes of subunits. The NR1 subunit possesses all properties of the NMDA receptor-channel complex, whereas four NR2 subunits (NR2A2D) potentiate and differentiate NMDA receptor responses by heteromeric assemblies with NR1. The mRNAs for the five NMDA receptor subunits are expressed in the cerebellum in a distinct temporospatial manner. To study functions of the NMDA receptors in the cerebellum, we generated knockout mice deficient in either NR2A or NR2C or both of these subunits. All three mutant mice developed normally and showed normal overall morphology of the cerebellum. The NMDA receptor-mediated components of EPSCs in granule cells, as assessed by whole-cell recordings of cerebellar slices, were reduced in NR2A- and NR2C-deficient mice and nearly abolished in mice lacking both NR2A and NR2C. The NR2A- and
NR2C-deficient granule cells were different in the current-voltage relationship and time course of NMDA receptor responses. The NR2A and NR2C subunits thus contribute to distinct NMDA receptor-mediated excitatory transmission in mossy fibergranule cell synapses in the mature cerebellum. Both NR2Aand NR2C-deficient mice showed no impaired movements in the motor coordination tasks tested. The mutant mice deficient in both NR2A and NR2C could also manage simple coordinated tasks, such as staying on a stationary or a slowly rotating rod, but failed more challenging tasks such as staying on a quickly rotating rod. These data demonstrate that the NMDA receptors play an active role in motor coordination.

Key words: NMDA receptor; glutamatergic transmission; gene targeting; whole-cell patch recording; EPSC; cerebellar granule cell; heteromeric receptor; motor coordination
Glutamate receptors mediate most excitatory synaptic transmission in the CNS and play important roles in synaptic plasticity, neuronal development, and neurodegeneration (Mayer and Westbrook, 1987; Nakanishi, 1992; Hollmann and Heinemann, 1994; Nakanishi and Masu, 1994). There are two general groups of glutamate receptors. Ionotropic glutamate receptors contain ligand-gated ion channels and are subdivided into NMDA receptors and non-NMDA receptors, whereas metabotropic glutamate receptors are G-protein-linked receptors that modulate the production of intracellular second messengers (Nakanishi, 1992; Hollmann and Heinemann, 1994; Nakanishi and Masu, 1994; Pin and Duvoisin, 1995).

NMDA receptors are thought to be essential in many central actions of glutamate, including learning, memory, cognitive processes, and neurodegenerative disorders. They have unique properties, including high permeability of $\mathrm{Ca}^{2+}$, modulation by glycine, voltage-dependent $\mathrm{Mg}^{2+}$ block, and inhibition by $\mathrm{Zn}^{2+}$ and specific channel blockers (Mayer and Westbrook, 1987; Nakanishi, 1992; Hollmann and Heinemann, 1994; Nakanishi and Masu,

\footnotetext{
Received May 13, 1996; revised Sept. 24, 1996; accepted Sept. 30, 1996.

This work was supported in part by research grants from the Ministry of Education, Science and Culture of Japan, the Ministry of Health and Welfare of Japan, the Uehara Memorial Foundation, and the Sankyo Foundation. We thank Drs. E. Molnár and P. Streit for their gift of the NR2A antibody, Drs. P. L. Chazot and F. A. Stephenson for their gift of the NR2C antibody, Dr. G. Katsuura for advice and assistance, Dr. S. R. Nash for reading this manuscript, and A. Uesugi, Y. Kikui, and M. Fukao for technical assistance.

Correspondence should be addressed to Shigetada Nakanishi, Department of Biological Sciences, Kyoto University Faculty of Medicine, Yoshida, Sakyo-ku, Kyoto 606, Japan.

Copyright (C) 1996 Society for Neuroscience $0270-6474 / 96 / 167859-09 \$ 05.00 / 0$
}

1994). NMDA receptors comprise heteromeric assemblies of different subunits, which are classified into two distinct groups (Kutsuwada et al., 1992; Meguro et al., 1992; Monyer et al., 1992; Ishii et al., 1993). The NR1 subunit is a fundamental subunit that shows all the properties of the NMDA receptor-channel complex (Moriyoshi et al., 1991). In contrast, none of the four NR2 subunits (NR2A-2D) show any receptor-channel activity in a homomeric configuration; however, the heteromeric assemblies of NR1 with one or more NR2 subunits seem to be required for functional NMDA receptor activities in vivo. These heteromeric assemblies markedly potentiate NMDA receptor activity and vary certain NMDA receptor properties, such as affinity for agonists, gating kinetics, unitary conductance, and sensitivity to antagonists and $\mathrm{Mg}^{2+}$ block (Kutsuwada et al., 1992; Monyer et al., 1992; Ishii et al., 1993).

NMDA receptors are believed to be critical in the formation of neural networks and the development and maturation of the cerebellum (Rabacchi et al., 1992; Komuro and Rakic, 1993). In the cerebellum, expressions of the mRNAs for the five NMDA receptor subunits are regulated in a distinct temporospatial manner (Akazawa et al., 1994; Watanabe et al., 1994). The NR1 mRNA is expressed in most neurons in the developing and mature cerebellum. The NR2A mRNA is present in granule cells from the early postnatal period to adulthood, whereas the NR2B mRNA is expressed transiently in these cells during the early postnatal period. The expression of the NR2D mRNA also occurs transiently in Purkinje cells during the postnatal period. The NR2C mRNA appears in granule cells in the third postnatal week and is predominantly expressed in mature granule cells. The 
biological significance for cerebellar function of the diversity of NMDA receptor subunits, however, remains to be understood.

As a first step for understanding the function of the different NMDA receptor subunits, we generated knockout mice deficient in either NR2A or NR2C or both of these subunits and studied NMDA receptor function in the cerebellum by examining NMDA receptor activity in cerebellar granule cells and the motor behaviors of the three mutant mice. The results demonstrate that a deficiency of either the NR2A or NR2C subunit causes no remarkable behavioral abnormality, but the disruption of both NR2A and NR2C results in impairment of motor coordination.

\section{MATERIALS AND METHODS}

Generation of NR2A- and/or NR2C-deficient mice. The NR2A and NR2C genes were isolated from a mouse genomic library prepared from $129 / \mathrm{SvJ}$ mice DNA (Stratagene, La Jolla, CA) by hybridization with the rat NR2A cDNA probe (residues 1483-2072) and the rat NR2C cDNA probe (residues 1833-2637), respectively (Ishii et al., 1993). For the construction of the targeting vector of the NR2A gene, we incorporated $13.9 \mathrm{~kb}$ of genomic sequence and replaced an internal $2.1 \mathrm{~kb} B a m \mathrm{HI}-B g I \mathrm{I}$ fragment encoding a part of the NR2A transmembrane segments with the neomycin resistance gene. For the NR2C gene, we incorporated $13.1 \mathrm{~kb}$ of genomic sequence and replaced an internal $1.5 \mathrm{~kb} S m a \mathrm{I}$ fragment encoding a part of the NR2C transmembrane segments with the neomycin resistance gene. A $2.1 \mathrm{~kb}$ herpes simplex virus thymidine kinase gene fragment was attached to the $3^{\prime}$ end of each targeting vector for negative selection. Electroporation of the targeting vector into embryonic stem (ES) cells, selection of ES cells containing the properly targeted gene, generation of chimeric mice, and germline transmission for the generation of heterozygous mutant mice were carried out according to the procedures described by Masu et al. (1995). The genotypes of 257 offspring obtained by NR2A heterozygote matings were $24.5 \%(63 / 257)$ homozygous mutant, $26.8 \%(69 / 257)$ wild type, and $48.7 \%(125 / 257)$ heterozygous mutant. The genotypes of 362 offspring obtained by NR2C heterozygote matings were $22.7 \%(82 / 362)$ homozygous mutant, $25.1 \%$ (91/362) wild type, and 52.2\% (189/362) heterozygous mutant. To generate homozygous mutant mice lacking both NR2A and NR2C, homozygous NR2A- and NR2C-deficient mice were first mated with each other, and the resultant mutant mice, heterozygous for both NR2A and NR2C, were inbred with each other. The genotypes of 248 offspring derived from NR2A and NR2C heterozygote matings were 5.2\% (13/248) homozygous mutant lacking both NR2A and NR2C, $6.0 \%$ wild type $(15 / 248)$, and $88.8 \%(220 / 248)$ heterozygous mutant containing at least one intact NR2 allelic gene.

Southern blot analysis of the NR2A and NR2C genes was carried out using tail DNA and hybridization with the $5^{\prime}$ and $3^{\prime}$ probe, respectively, as illustrated in Figure 1. Northern blot analysis of NR2A and NR2C mRNAs was performed by hybridization of total cerebellar RNA $(20 \mu \mathrm{g})$ with the rat NR2A cDNA probe (residues 1770-1982) and the rat NR2C cDNA probe (residues 1895-2263), respectively (Ishii et al., 1993). Western blot analysis was carried out with cerebellar membrane fractions. Antibodies used were a monoclonal antibody (23F6) directed against residues 439-453 of the NR2A subunit (Streit et al., 1995; a gift of Molnár and Streit), a polyclonal antibody against residues 1227-1237 of the NR2C subunit (Chazot et al., 1994), and a polyclonal antibody that reacts with the NR2C subunit as well as the NR2A and NR2B subunits (Calbiochem-Novabiochem, La Jolla, CA). The NR2A antibody preferably reacts with the deglycosylated NR2A subunit. Cerebellar membrane fractions were thus treated with peptide $N$-glycohydrolase F (Genzyme, Cambridge, MA) $(6 \mathrm{U} / \mathrm{ml})$ for $4 \mathrm{hr}$ before Western blot analysis.

Histological analysis. Animals (5-6 weeks old) were deeply anesthetized with sodium pentobarbital, and the brains were dissected rapidly. The tissue was immersed in a vial containing $45 \mathrm{ml}$ of $99 \%$ ethanol. The vial was stored at room temperature for a week, and $99 \%$ ethanol was changed every other day. The tissue was bisected on the midline, dehydrated, and embedded in paraffin. Sagittal sections were cut on a microtome at $4.5 \mu \mathrm{m}$. Nissl staining was carried out by immersing deparaffinized slides in $0.1 \%$ toluidine blue at $58^{\circ} \mathrm{C}$ for $1 \mathrm{hr}$. The cell density and sizes of granule cells were calculated from Nissl-stained sections.

Electrophysiology. Transverse slices $150 \mu \mathrm{m}$ thick were prepared from mice at postnatal days 18-20 using a microslicer and kept at room temperature for at least $1 \mathrm{hr}$ in the normal external solution containing (in mM): $124 \mathrm{NaCl}, 26 \mathrm{NaHCO}_{3}, 1.8 \mathrm{KCl}, 1.24 \mathrm{KH}_{2} \mathrm{PO}_{4}, 2.5 \mathrm{CaCl}_{2}, 1.3$
$\mathrm{MgCl}_{2}$, and 10 glucose, saturated with $95 \% \mathrm{O}_{2} / 5 \% \mathrm{CO}_{2}$. All experiments were performed with whole-cell configuration of the patch-clamp technique (Edwards et al., 1989) with borosilicate pipettes (resistance of 5-15 $\mathrm{M} \Omega$ when filled with an intracellular solution: $120 \mathrm{~mm} \mathrm{CsF}, 27 \mathrm{~mm} \mathrm{CsCl}_{2}$, $5 \mathrm{~mm}$ EGTA, $10 \mathrm{~mm}$ Hepes; $\mathrm{pH}$ adjusted to 7.3 with $\mathrm{CsOH}$ ). The recording chamber was perfused continuously with a solution of the following constituents (in mM): $109 \mathrm{NaCl}, 26 \mathrm{NaHCO}_{3}, 16.8 \mathrm{KCl}, 1.24$ $\mathrm{KH}_{2} \mathrm{PO}_{4}, 2.5 \mathrm{CaCl}_{2}, 0.1 \mathrm{MgCl}_{2}, 10$ glucose; and $20 \mu \mathrm{M}(+)$-bicuculline (Sigma, St. Louis, MO) (saturated with $95 \% \mathrm{O}_{2} / 5 \% \mathrm{CO}_{2}$ ). The external $\mathrm{K}^{+}$concentration was increased to enhance the frequency of spontaneous EPSCs, and $0.1 \mathrm{~mm} \mathrm{MgCl}_{2}$ was added to manifest a different sensitivity of $\mathrm{Mg}^{2+}$ block of the NR1/NR2A and NR1/NR2C assemblies at hyperpolarized potentials (Monyer et al., 1992; Ishii et al., 1993); (+)-bicuculline was added to suppress IPSCs. To record evoked synaptic responses, a slice was perfused with the normal external solution in which $5 \mu \mathrm{M}$ glycine and $10 \mu \mathrm{M}$ 6-cyano-7-nitroquinoxaline-2,3-dione (CNQX) were supplemented and $\mathrm{MgCl}_{2}$ was reduced to $0.1 \mathrm{~mm}$; glycine and CNQX were added to enhance NMDA receptor-mediated currents and suppress nonNMDA receptor-mediated currents, respectively. A glass pipette filled with the above external solution was placed around the recording granule cells, and $100 \mu \mathrm{sec}$ voltage pulses were applied to stimulate mossy fibers. Data were discarded when the drift of a junction potential during recording was $>5 \mathrm{mV}$. Recorded currents were filtered at $5 \mathrm{kHz}$, stored in a DAT recorder, and analyzed with QP-110J software (Nihon Kohden, Tokyo, Japan) on an NEC computer. All experiments were carried out at $20-23^{\circ} \mathrm{C}$.

Animal behavioral analysis. For measurements of locomotor activity and the number of rearing events, individual animals were placed in a novel environment of the circular open-field $(68 \mathrm{~cm}$ in diameter), in which the floor was divided into nine spaces by painted lines. The animal was observed directly, and the locomotor activity was counted as the number of line crossings in the open-field during a period of $3 \mathrm{~min}$. Under the same conditions, the number of rearing events was determined by counting the number of times the animal stood upright on its hindlimbs during a period of $3 \mathrm{~min}$, and the frequency of defecation and urination was measured during the same period. For analysis of the righting reflex, animals were lifted manually from the supporting surface and placed on their backs. Righting responses were recorded on video, and the time required for righting reflex was calculated. The grip strength was measured according to the procedure described by van Riezen and Boersma (1969), using similar equipment. Footprint analysis was carried out as described by Aiba et al. (1994). The fixed bar consisted of a wooden bar (either $6 \mathrm{~mm}$ or $20 \mathrm{~mm}$ in width, $80 \mathrm{~cm}$ in length, and $40 \mathrm{~cm}$ above the ground) held horizontally on both ends. An animal was placed on the fixed bar, and the animal behavior was recorded on videotape. The time the animal remained on the bar was measured. The rota-rod consisted of a gritted metal roller $(3 \mathrm{~cm}$ in diameter). A mouse was placed on the roller, and the time it remained on the rotating roller was measured. In both the fixed bar and rota-rod tests, a maximum of $60 \mathrm{sec}$ was allowed per animal. Statistical analysis was carried out by ANOVA, and post hoc comparisons were made with Scheffé test. The animals used for all behavioral experiments were 5-6 weeks old.

\section{RESULTS}

\section{Generation of NR2A- and/or NR2C-deficient mice}

We cloned and mapped the mouse NR2A and NR2C genes and disrupted them in the ES cell line derived from the 129/SvJ mouse strain (Wurst and Joyner, 1993). Each targeting vector included the neomycin resistance gene for positive selection and the herpes simplex virus thymidine kinase gene for negative selection (Fig. $1 A$ ). For targeted disruption of the NR2A and NR2C genes, the region covering the second transmembrane segment of the NR2 subunits was replaced with the neomycin resistance gene (Fig. $1 A$ ). The targeting vector was electroporated into ES cells, which were then selected with G418 and the pyrimidine analog gancyclovir. Southern blot analysis was carried out to identify targeted clones from G418- and gancyclovir-resistant clones. Three NR2Atargeted and four NR2C-targeted clones were isolated from 33 and 60 clones, respectively. Chimeric mice were generated by injecting the targeted ES clones into C57BL/6J blastocysts. The targeted mutations of both NR2A and NR2C genes were trans- 
A

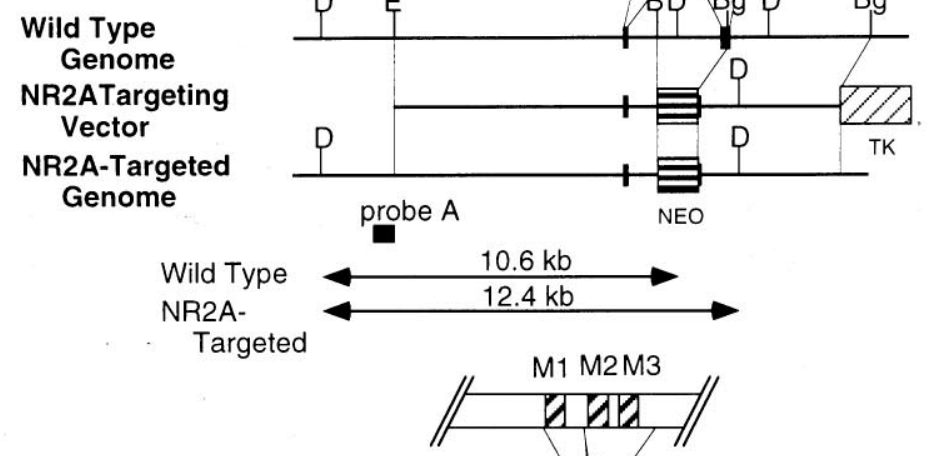

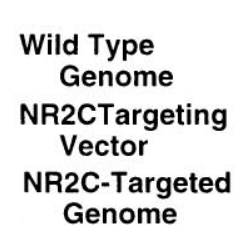

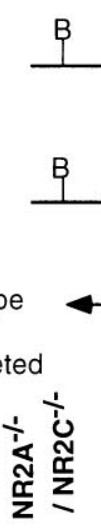

- NR2A-Targeted (12.4kb)

C

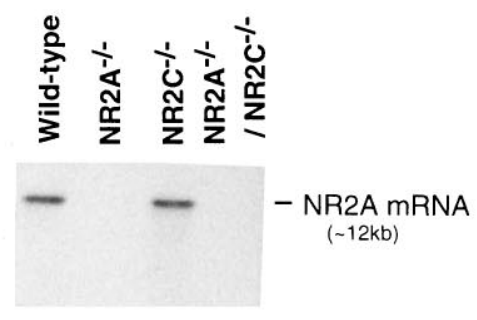

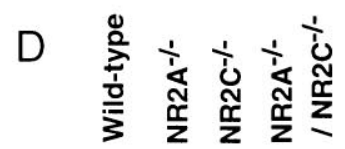

- NR2A ( 170kD)

B
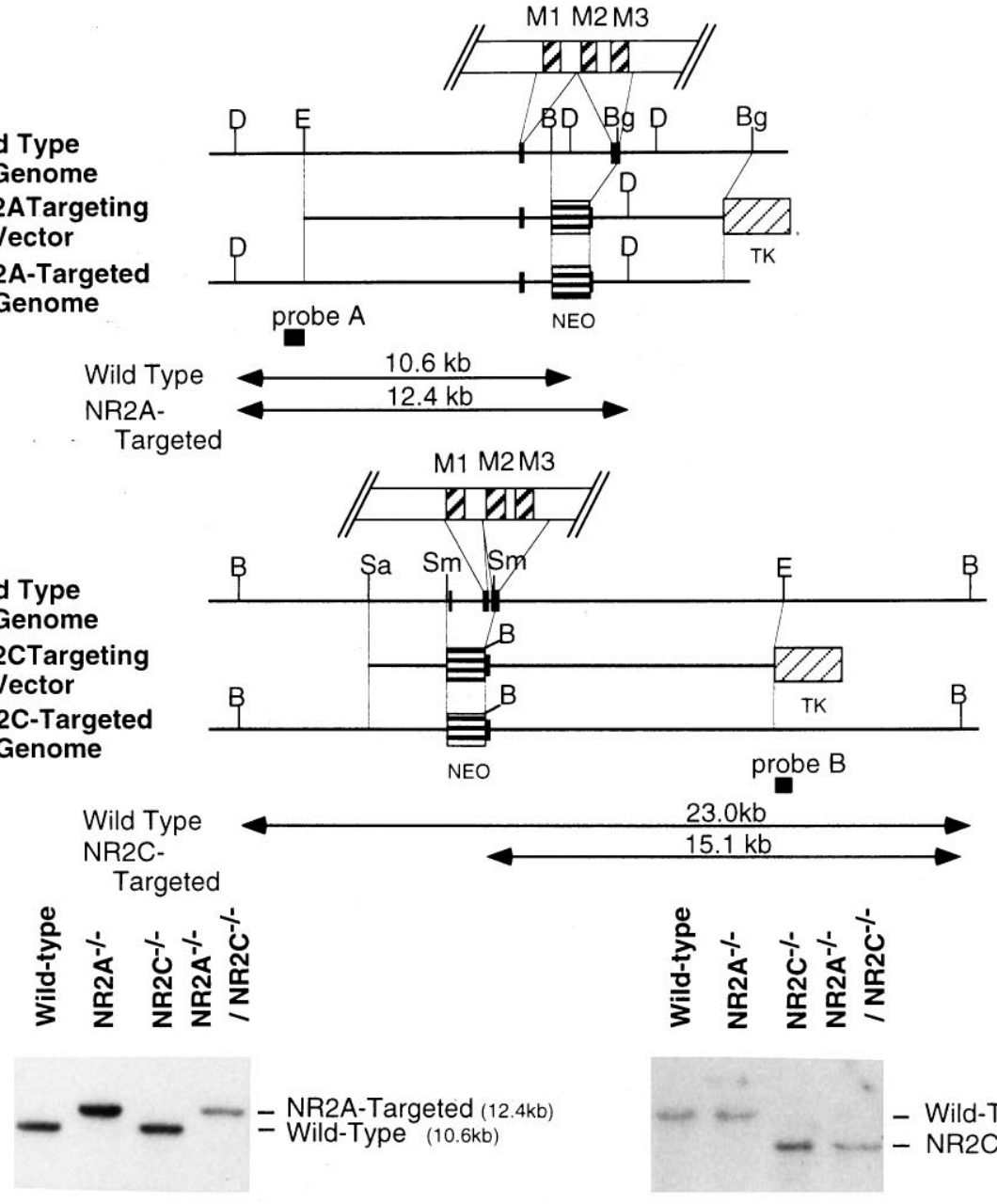

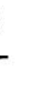

\section{五}
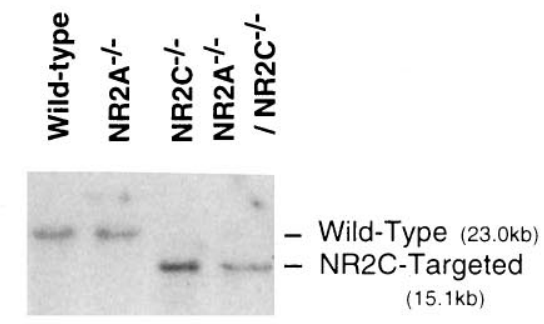

Figure 1. Targeted disruption of the NR2A and NR2C genes. $A$, Exons of the NR2A (top) and NR2C (bottom) genes around the disrupted sites are shown by closed boxes. Homologous recombination resulted in replacement of the 2.1 $\mathrm{kb}(\mathrm{NR} 2 \mathrm{~A})$ or $1.5 \mathrm{~kb}$ (NR2C) fragment encoding the putative transmembrane region $(M 2$ and $M 3$ for NR2A; $M 1$ and $M 2$ for NR2C) with the neomycin resistance gene (NEO). The herpes simplex virus thymidine kinase gene $(T K)$ was attached to the $3^{\prime}$ end of each targeting vector for negative selection. Restriction sites indicated are as follows: $D, D r a \mathrm{II}$; $E, E c o$ RI; $B, B a m \mathrm{HI} ; B g, B g l \mathrm{I} ; S a, S a l$ I; and $S m$, SmaI. The locations of the probes used for Southern blot analysis are indicated. $B$, Southern blot analysis of genomic DNAs from the Wild-type, NR2A-disrupted $\left(N R 2 A^{-/-}\right)$, NR2Cdisrupted $\left(\mathrm{NR} 2 \mathrm{C}^{-/-}\right)$, and both NR2Aand NR2C-disrupted $\left(N R 2 A^{-1-} /\right.$ $N R 2 C^{-1-}$ ) mice. DraII-digested DNAs were hybridized with probe $A$ for the analysis of NR2A gene disruption (left), and BamHI-digested DNAs were hybridized with probe $B$ for the analysis of NR2C gene disruption (right). $C$, Northern blot analysis of expression of the NR2A mRNA (left) or NR2C mRNA (right) in the cerebellum of the wildtype and homozygous $\mathrm{NR}_{2} \mathrm{~A}^{-1-}$, $\mathrm{NR} 2 \mathrm{C}^{-/-}$, and $\mathrm{NR} 2 \mathrm{~A}^{-/-} / \mathrm{NR} 2 \mathrm{C}^{-/-} \mathrm{mu}-$ tant mice. The NR2A mRNA is absent in the $\mathrm{NR} 2 \mathrm{~A}^{-1-}$ and $\mathrm{NR} 2 \mathrm{~A}^{-1-} /$ $\mathrm{NR} 2 \mathrm{C}^{-/-}$mice, whereas the $\mathrm{NR} 2 \mathrm{C}$ mRNA is absent in the $\mathrm{NR}^{-1} \mathrm{C}^{-1-}$ and $\mathrm{NR}_{2} \mathrm{~A}^{-1-} / \mathrm{NR}_{2} \mathrm{C}^{-/-}$mice. $D$, Western blot analysis using an antibody that preferably reacts with the deglycosylated NR2A subunit ( $\sim 170 \mathrm{kDa})$ (left) and an antibody that reacts with the NR2C subunit $(\sim 140 \mathrm{kDa})$ as well as the NR2A and NR2B subunits $(\sim 180 \mathrm{kDa})$ (right). NR2A immunoreactivity is absent in cerebellar membrane fractions from the $\mathrm{NR} 2 \mathrm{~A}^{-1-}$ and $\mathrm{NR}_{2} \mathrm{~A}^{-/-} / \mathrm{NR} 2 \mathrm{C}^{-/-}$ mice, whereas NR2C immunoreactivity is absent in cerebellar membrane frac-

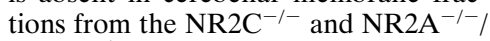
$\mathrm{NR} 2 \mathrm{C}^{-/-}$mice. mitted into the germline, and heterozygous and homozygous mutant mice containing the properly targeted NR2A or NR2C gene were identified by Southern blot analysis (Fig. 1B). Homozygous NR2A (NR2A ${ }^{-/-}$) and NR2C mutant mice $\left(\mathrm{NR}_{2} \mathrm{C}^{--}\right)$ were mated to generate double-mutant mice lacking both NR2A and NR2C (NR2A $\left.{ }^{-1-} / \mathrm{NR} 2 \mathrm{C}^{-/-}\right)$.

As reported previously (Sakimura et al., 1995), homozygous
$\mathrm{NR} 2 \mathrm{~A}^{-/-}$mutant mice developed and mated normally. Similarly, both homozygous $\mathrm{NR} 2 \mathrm{C}^{-/-}$mutant mice and $\mathrm{NR}_{2} \mathrm{~A}^{-1-}$ / $\mathrm{NR} 2 \mathrm{C}^{-1-}$ mutant mice showed no apparent survival disadvantage or any obvious abnormality in their appearance as compared with their wild-type littermates. Northern blot analysis confirmed the lack of either NR2A mRNA or NR2C mRNA or both in cerebellar RNAs of the corresponding homozygous mutant mice (Fig. 
Wild-type
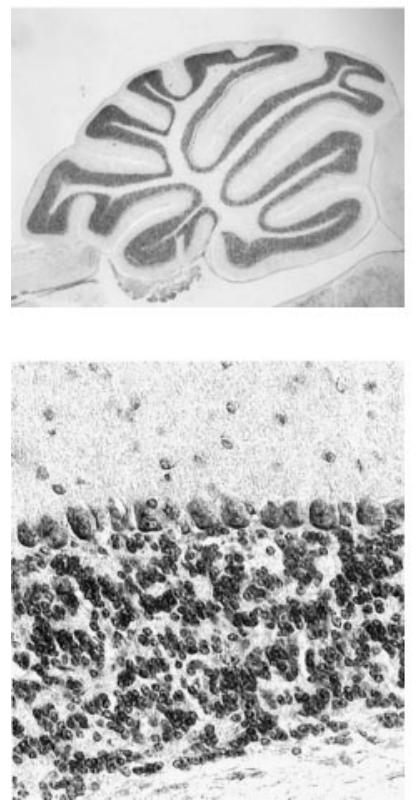

NR2A $/-$
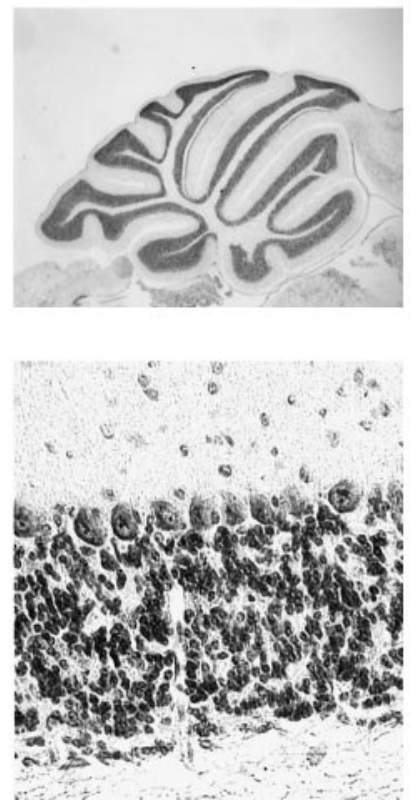

$\mathrm{NR} 2 \mathrm{C}-1-$
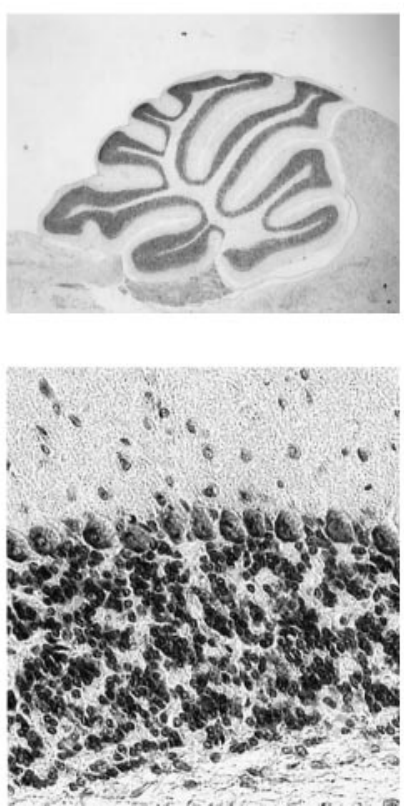

NR2A-/- / NR2C-/-
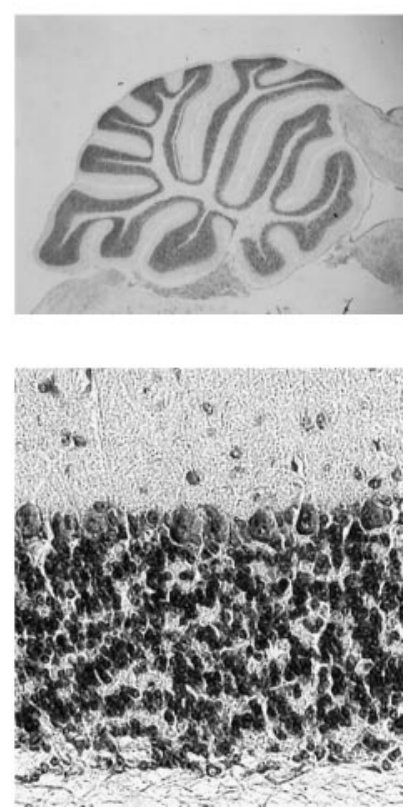

Figure 2. Histological analysis of the cerebellum. Parasagittal sections of the cerebellum were treated with Nissl staining (top), and magnified views covering the granule cell layer are indicated (bottom). The number of granule cells was calculated to be $2.9 \times 10^{4} \pm 4.2 \times 10^{3} / \mathrm{mm}^{2}($ Wildtype $), 3.0 \times 10^{4} \pm 2.1 \times 10^{3} / \mathrm{mm}^{2}\left(N R 2 A^{-1-}\right), 3.0 \times 10^{4} \pm 8.6 \times 10^{2} / \mathrm{mm}^{2}\left(N R 2 C^{-1-}\right)$, and $3.1 \times 10^{4} \pm 2.7 \times 10^{3} / \mathrm{mm}^{2}\left(N R 2 A^{-1-} / N R 2 C^{-/-}\right)$. The size of the granule cells was determined to be $4.55 \pm 0.31 \mu \mathrm{m}$ (Wild-type), $4.51 \pm 0.29 \mu \mathrm{m}\left(N R 2 A^{-/-}\right), 4.48 \pm 0.31 \mu \mathrm{m}\left(N R 2 C^{-/-}\right)$, and $4.44 \pm 0.33 \mu \mathrm{m}$ $\left(N R 2 A^{-1-} / N R 2 C^{-1-}\right) . n=3$ animals for each genotype.

1C). The disappearance of immunoreactivity for NR2A or NR2C or both was confirmed by Western blot analysis of cerebellar membrane fractions of the respective homozygous mutant mice (Fig. 1D).

\section{Histological analysis}

The three different mutant mice showed no gross anatomical changes in the brain. In the adult cerebellum, the NR2A mRNA is distributed in granule cells and cerebellar nuclear neurons, whereas the NR2C mRNA is predominantly expressed in granule cells (Akazawa et al., 1994; Watanabe et al., 1994). Nonetheless, as viewed by Nissl staining, the cellular organization of the cerebellum was unaltered in all three mutant mice (Fig. 2). The sizes and density of granule cells, as calculated by more magnified visualization (Fig. 2), were indistinguishable among the wild-type and three mutant mice.

\section{Mossy fiber-granule cell EPSCs}

In the mossy fiber-granule cell synapses of the cerebellum, the activation of non-NMDA receptors and NMDA receptors has been shown to evoke the fast and slow components of EPSCs, respectively (Silver et al., 1992; D'Angelo et al., 1993). To investigate NMDA receptor responses in mutant mice, we first characterized spontaneous EPSCs of granule cells by whole-cell patch-clamp recordings in cerebellar slice preparations from the wild-type and three NR2 mutant mice at postnatal days 18-20. Spontaneous EPSC traces of the four genotypes recorded at different membrane potentials are presented in Figure $3 A$. In the wild-type mice, spontaneous EPSCs consisted of a fast component and the following slow component. The fast component had a rapid rising phase and decayed in a few milliseconds, whereas the slow component lasted for hundreds of milliseconds. This pattern of EPSCs in mouse slice preparations agreed with the pattern of the fast and slow components that are characteristic of the nonNMDA and NMDA receptors, respectively, in rat cerebellar slice preparations (Silver et al., 1992; D’Angelo et al., 1993). We also confirmed that the slow component, but not the fast component, of EPSCs was abolished by the addition of the NMDA receptor antagonist D-2-amino-5-phosphonovalerate (D-AP5) $(n=5$; data not shown).

In recordings of the three mutant genotypes, the fast component was elicited in granule cells, but the magnitude of the slow component differed from those of the wild-type genotype. It has been shown by coexpression of recombinant NR1 and NR2 subunits in Xenopus oocytes or transfected cells that the NR1/NR2A assembly is more sensitive to $\mathrm{Mg}^{2+}$ block than the NR1/NR2C assembly at hyperpolarized potentials (Kutsuwada et al., 1992; Meguro et al., 1992; Monyer et al., 1992; Ishii et al., 1993). The differences of NMDA receptor responses among the four genotypes were characterized more quantitatively by comparing the slow components of EPSCs in the four genotypes as presented in Figure $3 B-D$. The current-voltage plots of the magnitude of the fast component (peak amplitude of the fast component) were linear in all four genotypes, consistent with the properties of non-NMDA receptor responses. In contrast, the amplitude of the slow component (10 msec after the peak of the fast component) was reduced at hyperpolarized potentials in both the wild-type and NR2A ${ }^{-1-}$ mutant mice (Fig. 3B). This reduction was more marked in the $\mathrm{NR} 2 \mathrm{C}^{-/-}$mutant mice, and the slow component nearly disappeared in the $\mathrm{NR}_{2} \mathrm{~A}^{-/-} / \mathrm{NR} 2 \mathrm{C}^{-/-}$mutant mice (Fig. $3 B$ ). When the relative magnitude of the fast and slow components was calculated at $-80 \mathrm{mV}$, this ratio in both the $\mathrm{NR} 2 \mathrm{~A}^{-1-}$ and $\mathrm{NR} 2 \mathrm{C}^{-1-}$ mutant mice was reduced to about half of that of the wild-type mice $(p<0.01)$, and the ratio in the $\mathrm{NR}_{2} \mathrm{~A}^{-1-} /$ $\mathrm{NR} 2 \mathrm{C}^{-/-}$mutant mice was almost negligible $(p<0.01)$ (Fig. $3 C$ ). 


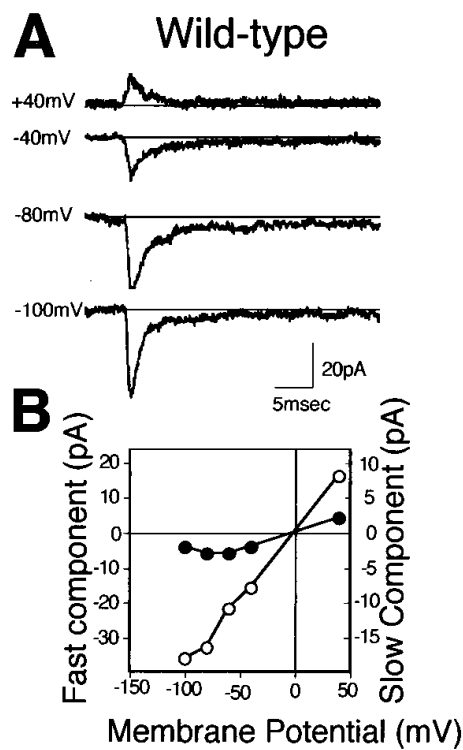

C

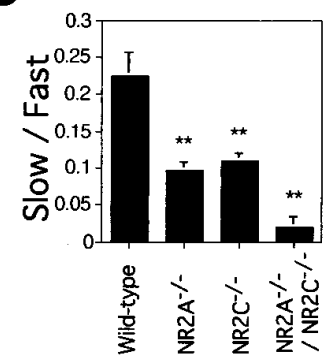

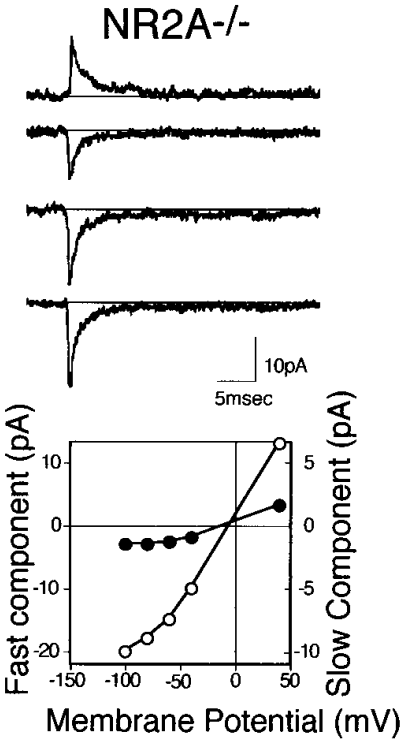
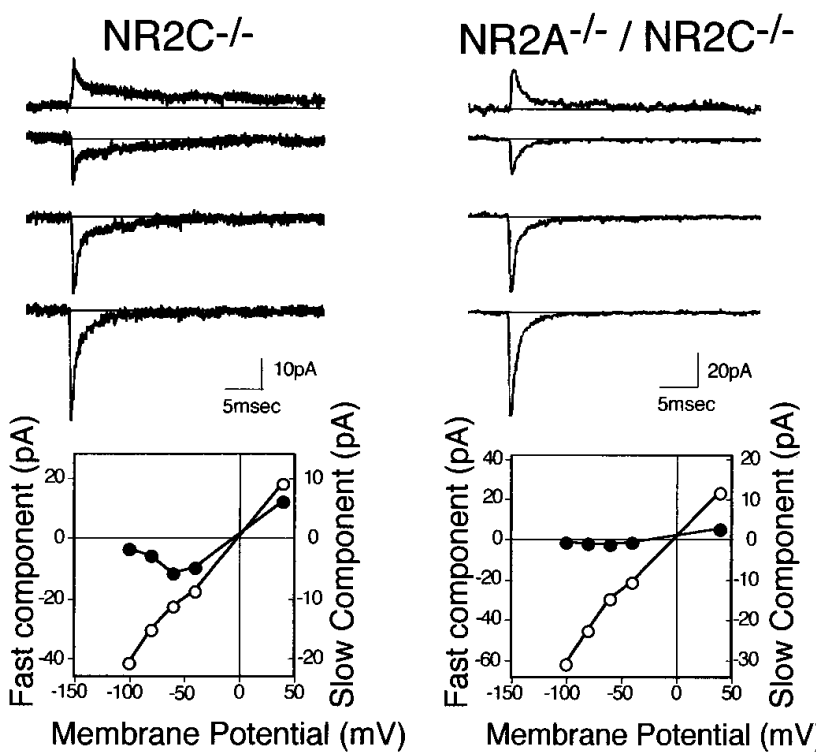

Membrane Potential (mV)
D

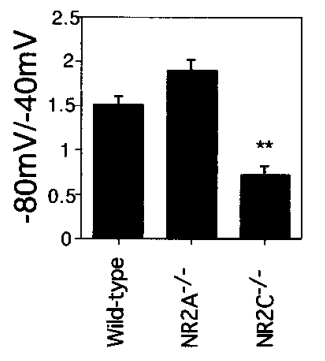

Figure 3. Spontaneous mossy fiber-granule cell EPSCs. A, Spontaneous EPSCs were recorded from single granule cells of the four genotypes under voltage clamp at 40,-40,-80, and $-100 \mathrm{mV}$, and 5-10 traces are averaged and indicated. $B$, Magnitudes of the fast component (open circles, measured as the peak amplitude) and the slow component (filled circles, measured at $10 \mathrm{msec}$ after the peak of the fast component) of EPSCs of the four genotypes are plotted against the clamping voltages. $C$, Relative amplitudes of the slow component against the fast component measured at $-80 \mathrm{mV}$ are indicated.

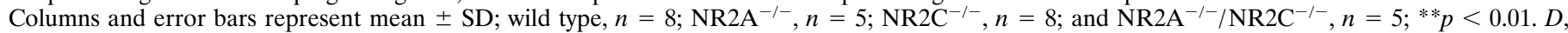
Relative amplitudes of the slow component measured at $-80 \mathrm{mV}$ against that measured at $-40 \mathrm{mV}$ are indicated; $n=5$ for each genotype; ** $p<0.01$.

Furthermore, when the relative magnitudes of the slow component measured at $-80 \mathrm{mV}$ against that of $-40 \mathrm{mV}$ were compared, this ratio slightly increased in the $\mathrm{NR} 2 \mathrm{~A}^{-1-}$ mutant mice but greatly decreased in the $\mathrm{NR} 2 \mathrm{C}^{-1-}$ mutant mice as compared with that of the wild-type mice $(p<0.01)$ (Fig. $3 D)$.

It has been shown that the decay time of NMDA receptor responses of the recombinant NR1/NR2A assembly is significantly faster than that of the recombinant NR1/NR2C assembly (Monyer et al., 1992). We examined pharmacologically isolated NMDA receptor-mediated EPSCs that were evoked by mossy fiber stimulation in the presence of the non-NMDA receptor antagonist CNQX. EPSCs were recorded from granule cells of the wild-type and the $\mathrm{NR} 2 \mathrm{~A}^{-1-}$ and $\mathrm{NR} 2 \mathrm{C}^{-1-}$ mutant mice, and these evoked EPSCs were abolished by the addition of D-AP5 (Fig. 4). No such responses were detected in any of the granule cells examined from the $\mathrm{NR} 2 \mathrm{~A}^{-1-} / \mathrm{NR} 2 \mathrm{C}^{-1-}$ mutant mice $(n=$ 9). The rise time of the NMDA receptor-mediated EPSCs was similar among the three genotypes (Table 1). The decay time, however, was slightly slower in the $\mathrm{NR}_{2} \mathrm{~A}^{-/-}$mutant mice than in the wild-type mice and was faster in the $\mathrm{NR} 2 \mathrm{C}^{-1-}$ mutant mice (Table 1). The time course of the NMDA receptor-mediated EPSCs of wild-type granule cells could be fitted to the sum of two exponential functions, as observed previously in rat granule cells (D'Angelo et al., 1994). The NR2A ${ }^{-/-}$and NR2C ${ }^{-/-}$mutant
Table 1. Kinetic properties of pharmacologically isolated NMDA receptor-mediated EPSCs

\begin{tabular}{lccc} 
& Wild type & $\mathrm{NR}^{-1-}$ & $\mathrm{NR}^{-/ C^{-/}}$ \\
\hline Rise time $(\mathrm{msec})$ & $8.7 \pm 2.0$ & $8.6 \pm 2.2$ & $6.0 \pm 0.9$ \\
Decay time $(\mathrm{msec})$ & $77.7 \pm 18.2$ & $97.7 \pm 19.4$ & $33.1 \pm 6.9$ \\
Decay time constant & & & \\
$\tau N_{\text {fast }}(\mathrm{msec})$ & $25.3 \pm 3.4$ & $34.8 \pm 5.4$ & $10.8 \pm 0.9^{*}$ \\
$\tau N_{\text {slow }}(\mathrm{msec})$ & $360 \pm 53$ & $674 \pm 151^{*}$ & $157 \pm 14$ \\
$N_{\text {fast }} / N_{\text {slow }}$ & $2.6 \pm 0.7$ & $2.0 \pm 0.4$ & $3.1 \pm 1.5$
\end{tabular}

All data are given as mean \pm SEM. Data are derived from measurements of six to nine cells in each group. NMDA receptor-mediated synaptic currents were recorded at $-80 \mathrm{mV}$ in the presence of CNQX $(10 \mu \mathrm{M})$, glycine $(5 \mu \mathrm{M})$, and $0.1 \mathrm{~mm} \mathrm{Mg}$. Rise time represents time to peak, and decay time represents time from peak to $1 /$ e. $N_{\text {fast }} / N_{\text {slow }}$ represents the relative ratio of the fast and slow components of decay in NMDA receptor-mediated EPSCs. ${ }^{*} p<0.05$.

mice also displayed a double-exponential decay. The time constants of both fast and slow components of decay $\left(\tau N_{\text {fast }}\right.$ and $\left.\tau N_{\text {slow }}\right)$ increased in the $\mathrm{NR}_{2} \mathrm{~A}^{-1-}$ mutant mice and decreased in the $\mathrm{NR} 2 \mathrm{C}^{-1-}$ mutant mice as compared with the wild-type mice (Table 1). Thus, taking into account the difference in $\mathrm{Mg}^{2+}$ sensitivity at the hyperpolarized potentials and the time course of the NMDA receptor currents between the recombinant NR1/ 


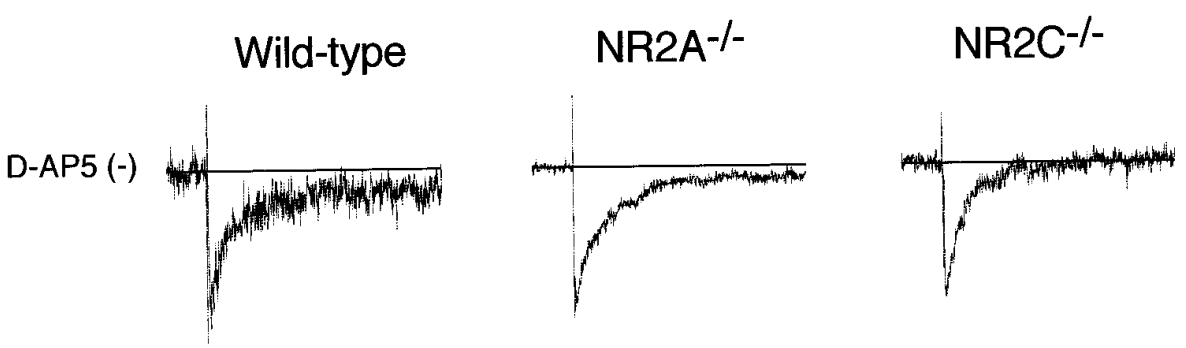

Figure 4. Granule cell EPSCs elicited by mossy fiber stimulation. EPSCs elicited by mossy fiber stimulation were recorded in the presence of $10 \mu \mathrm{M}$ CNQX, $5 \mu \mathrm{M}$ glycine, and $0.1 \mathrm{mM} \mathrm{Mg}^{2+}$ from single granule cells of the wild-type and $\mathrm{NR} 2 \mathrm{~A}^{-1-}$ and $\mathrm{NR} 2 \mathrm{C}^{-1-} \mathrm{mu}-$ tant mice under voltage clamp at $-80 \mathrm{mV}$. Fourteen to sixteen traces recorded in the absence (top) and presence (bottom) of 100 $\mu \mathrm{M}$ D-AP5 are averaged and indicated.
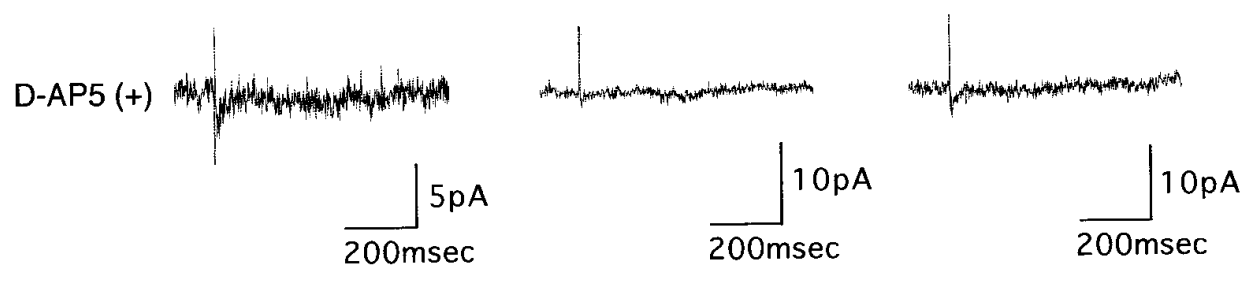

\section{A Locomotor Activity}

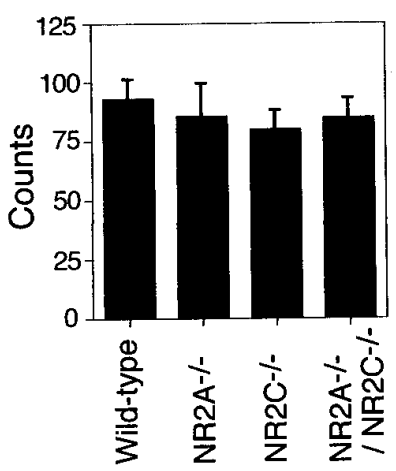

B

Rearing

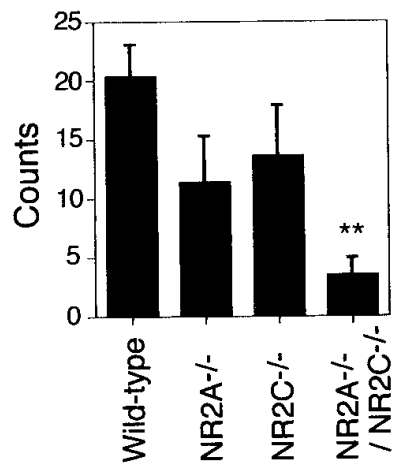

Figure 5. Open-field test. A, A mouse was placed in a novel environment of the open-field, and its locomotor activity was determined by counting the number of line crossings in the open-field during the first $3 \mathrm{~min} . B$, Under the above condition, the number of rearing events was determined by counting the number of times the animal stood upright on its hindlimbs for the first $3 \mathrm{~min}$. In both $A$ and $B, n=10$ for wild type, $n=7$ for $\mathrm{NR}_{2} \mathrm{~A}^{-1-}$ and $\mathrm{NR} 2 \mathrm{C}^{-1-}$, and $n=13$ for $\mathrm{NR} 2 \mathrm{~A}^{-1-} / \mathrm{NR} 2 \mathrm{C}^{-1-}$. Columns and error bars represent mean $\pm \mathrm{SEM} ;{ }^{*} p<0.01$.

NR2A and NR1/NR2C heteromeric receptors (Kutsuwada et al., 1992; Meguro et al., 1992; Monyer et al., 1992; Ishii et al., 1993), the results indicate that in cerebellar granule cells, ablation of either NR2A or NR2C alone retains NMDA receptor activity derived from the NR1/NR2C and NR1/NR2A heteromeric assemblies, respectively, and that deficit of both NR2A and NR2C results in an almost complete loss of NMDA receptor activity.

\section{Motor coordination}

None of the three mutant mice showed any ataxic gait or any sign of tremor. These mutants walked normally on the ground, and analysis of hind footprints of the four genotypes showed no difference in either the walking line or the length of steps. The general locomotor activities of the four genotypes were compared by the open-field test (Fig. 5). There was no difference in the horizontal locomotor activities of the four genotypes as quantified by counting the number of line crossings in the open-field (Fig. 5A); however, the amount of vertical activity as measured by rearing was slightly decreased in both the $\mathrm{NR} 2 \mathrm{~A}^{-1-}$ and $\mathrm{NR} 2 \mathrm{C}^{-/-}$mutant mice and significantly lowered in the $\mathrm{NR}_{2} \mathrm{~A}^{-/-} / \mathrm{NR} 2 \mathrm{C}^{-/-}$mutant mice $(p<0.01)$ (Fig. $5 B$ ).

\begin{abstract}
Table 2. Animal behavioral analysis

\begin{tabular}{lllll} 
& Wild type & $\mathrm{NR}^{-/-}$ & $\mathrm{NR}^{-1-} \mathrm{C}^{-/-}$ & $\begin{array}{l}\mathrm{NR}^{-1} \mathrm{~A}^{-/-} \\
\mathrm{NR}^{-/-}\end{array}$ \\
\hline $\begin{array}{l}\text { Defecation } \\
\text { (count/3 min) }\end{array}$ & $1.68 \pm 0.35$ & $1.81 \pm 0.34$ & $1.42 \pm 0.35$ & $2.04 \pm 0.32$ \\
$\begin{array}{l}\text { Urination } \\
\quad \text { count/3 min) }\end{array}$ & $0.25 \pm 0.14$ & $0.44 \pm 0.13$ & $0.50 \pm 0.15$ & $0.42 \pm 0.15$ \\
$\begin{array}{l}\text { Grip strength } \\
\text { Righting reflex }\end{array}$ & $66.4 \pm 1.6$ & $66.0 \pm 1.7$ & $64.8 \pm 1.1$ & $66.0 \pm 1.6$ \\
$\quad(\mathrm{sec})$ & $0.18 \pm 0.08$ & $0.19 \pm 0.07$ & $0.19 \pm 0.08$ & $0.19 \pm 0.09$
\end{tabular}
\end{abstract}

All data are given as mean \pm SEM. For analysis of defecation and urination, an animal was placed in a novel environment of the open-field, and the frequency of defecation and urination was measured during the first $3 \mathrm{~min}$. The grip strength and the time required for righting reflex were measured according to the procedures described in Materials and Methods. The numbers of animals tested were 16-24 for the analyses of defecation and urination and 5 for the analyses of grip strength and righting reflex. No statistically significant difference was noted for any of the animal behaviors analyzed.

Because the frequency of either defecation or urination was unaltered among the four genotypes (Table 2), the difference of the rearing behavior does not seem to result from changes in emotional or exploratory behavior. The grip strength and righting reflex were also unchanged among the four genotypes (Table 2). It thus seems unlikely that weakness of muscle strength is responsible for the decrease in rearing behavior in the mutant mice.

To further assess the possibility of a motor discoordination, we performed a fixed bar test. We initially used a wide wooden bar (20 mm in width) and found that all four genotypes could walk smoothly and stay on the bar with no difference (Fig. 6B). We then used a narrower wooden bar $(6 \mathrm{~mm}$ in width). The wild-type and $\mathrm{NR}_{2} \mathrm{~A}^{-1-}$ and $\mathrm{NR} 2 \mathrm{C}^{-/-}$mutant mice could again stand up and walk smoothly on the narrow wooden bar (Fig. 6A). In contrast, the $\mathrm{NR} 2 \mathrm{~A}^{-/-} / \mathrm{NR} 2 \mathrm{C}^{-/-}$mice could not stand up, and they shinnied along the bar by grasping and pulling with their forepaws and dragging their hindlimbs (Fig. 6A). Furthermore, the $\mathrm{NR} 2 \mathrm{~A}^{-/-} / \mathrm{NR} 2 \mathrm{C}^{-1-}$ mice fell off the bar more quickly than the others $(p<0.01)$ (Fig. 6B), and this deficit could not be improved by training for $5 \mathrm{~d}$ (data not shown).

To further characterize the motor discoordination, we employed a rota-rod test using a gritted roller $(3 \mathrm{~cm}$ in diameter) (Fig. 7). All of the four genotypes could remain on the stationary 
A

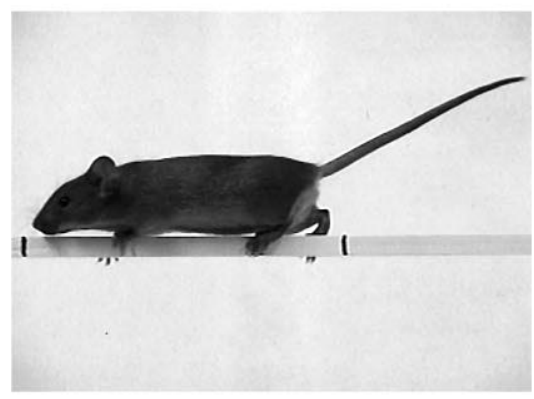

Wild-type

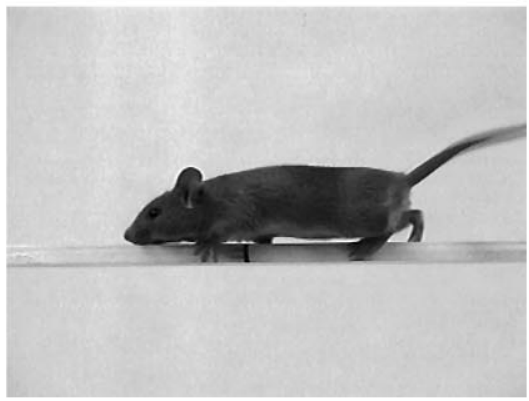

$\mathrm{NR} 2 \mathrm{C}^{-/-}$
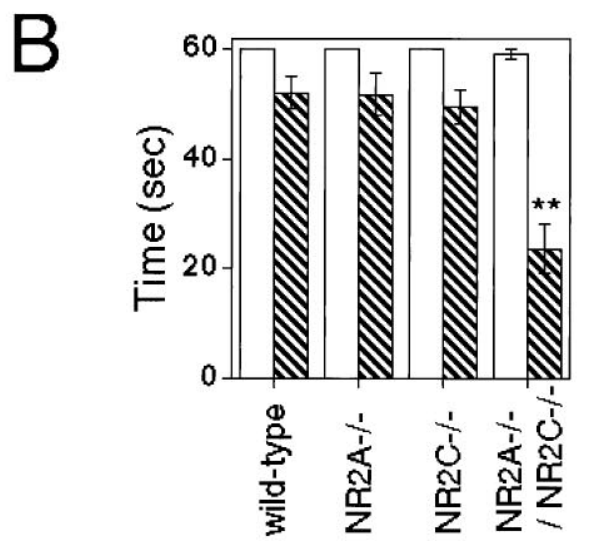

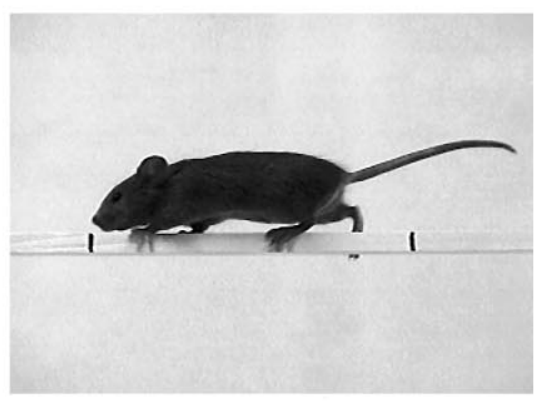

$\mathrm{NR} 2 \mathrm{~A}^{-/-}$

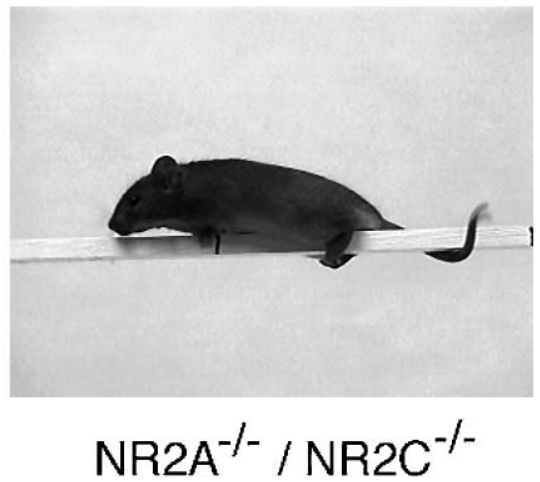

Figure 6. Fixed bar test. A, Photographs of mouse behavior in the fixed bar test. A mouse was placed on the midpoint of the 6-mm-wide fixed bar, and animal behavior was videotaped.

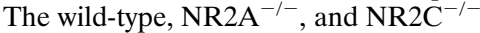
mutant mice walked normally on the narrow bar, but the NR2A ${ }^{-1-} / \mathrm{NR} 2 \mathrm{C}^{-1-}$ mutant mouse showed a characteristic movement of grasping and pulling with its forepaws and dragging its hindlimbs. $B$, The time an animal remained on the bar of either $20 \mathrm{~mm}$ (open column) $(n=$ $6-7$ ) or $6 \mathrm{~mm}$ in width (column with diagonal lines $)(n=17-27)$ was measured for a maximum of $60 \mathrm{sec}$. Columns and error bars represent mean \pm SEM. NR2A ${ }^{-1-} / \mathrm{NR}_{2} \mathrm{C}^{-/-}$mice spent significantly less time on the 6-mm-wide bar than did the other mice; ${ }^{*} p<0.01$. rota-rod for the period of time allowed $(60 \mathrm{sec})$. When the rota-rod was running at either $10 \mathrm{rpm}$ or $20 \mathrm{rpm}$, all genotypes stayed on the rota-rod with no significant difference (Fig. $7 A$ ); however, when the rod was running more quickly $(25 \mathrm{rpm})$, the $\mathrm{NR} 2 \mathrm{~A}^{-1-} / \mathrm{NR} 2 \mathrm{C}^{-1-}$ mice failed to stay on the rotating $\operatorname{rod}(P<$ $0.05)$ (Fig. 7A). Furthermore, a clear difference in improvement of performance at $20 \mathrm{rpm}$ was observed in the $\mathrm{NR} 2 \mathrm{~A}^{-/-} / \mathrm{NR} 2 \mathrm{C}^{-/-}$ mice when the training proceeded from day 1 to day 5 (Fig. $7 B$ ). Thus, ablation of NR2A or NR2C alone causes no obvious motor discoordination. Similarly, mice deficient in both NR2A and $\mathrm{NR} 2 \mathrm{C}$ retain the ability to manage simple coordinated tasks such as walking on the ground or staying on the stationary or slowly running rota-rod. The $\mathrm{NR} 2 \mathrm{~A}^{-/-} / \mathrm{NR} 2 \mathrm{C}^{-/-}$mice cannot adapt, however, to more challenging tasks such as walking on the narrow bar or staying on the quickly running rota-rod.

\section{DISCUSSION}

In this investigation, we generated knockout mice deficient in either NR2A or NR2C or both of the NMDA receptor subunits. This permitted an examination of the function of the NR2A and/or NR2C subunits in glutamatergic transmission between mossy fibers and cerebellar granule cells as well as of the effects of the deficiency of these subunits on motor coordination.

The mRNAs encoding the five NMDA receptor subunits show differential expressions in developing and adult cerebellum (Akazawa et al., 1994; Watanabe et al., 1994). In cerebellar granule cells, 
A

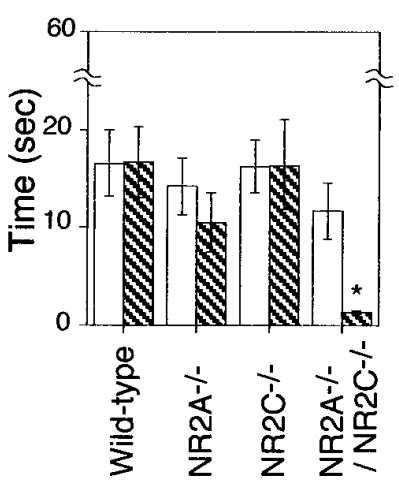

Figure 7. Rota-rod test. $A$, The time an animal remained on a rota-rod rotated at either $20 \mathrm{rpm}$ (open column) or $25 \mathrm{rpm}$ (column with diagonal lines) was measured on day 1 without training. Columns and error bars represent mean $\pm \mathrm{SEM}$. The $\mathrm{NR} 2 \mathrm{~A}^{-1-} / \mathrm{NR} 2 \mathrm{C}^{-/-}$mice spent significantly less time on the rota-rod rotated at $25 \mathrm{rpm}$ than did the others $\left({ }^{*} p<0.05\right)$. At least 20 animals were tested for each genotype. $B$, The time an animal remained on a rotating rota-rod $(20 \mathrm{rpm})$ was measured during training by two trials per day. A maximum of $60 \mathrm{sec}$ was allowed for each animal per trial. $\bigcirc$, Wild type $(n=33)$; $\square$, NR2A $\mathrm{A}^{-l-}(n=30) ; \bigcirc, \mathrm{NR}^{-1-} \mathrm{C}^{-1-}(n=$ $35)$;, $\mathrm{NR} 2 \mathrm{~A}^{-1-} / \mathrm{NR} 2 \mathrm{C}^{-1-}(n=25)$. The $\mathrm{NR}^{-1} \mathrm{~A}^{-1-} / \mathrm{NR} 2 \mathrm{C}^{-1-}$ mice spent significantly less time than did the others $(p<0.05)$, although their performance did improve $\left(F_{(4,96)}=9.98 ; p<0.01\right)$. Marks and error bars represent mean $\pm \mathrm{SEM}$.

the NR1 mRNA is expressed at all developmental and mature stages. The NR2A and NR2B mRNAs appear in the external granular layer from postnatal day 3, whereas the expression of NR2C mRNA begins at the third postnatal week. In contrast, no NR2D mRNA is expressed at any developmental stage of granule cells. The expression of the NR2A and NR2C mRNAs continues or increases in mature granule cells, whereas the expression of the NR2B mRNA disappears during maturation of granule cells. The present examination by whole-cell patch-clamp recordings has indicated that deficit of either NR2A or NR2C alone reduces the NMDA receptor-mediated component of EPSC in granule cells of the mature cerebellum. Relative amplitudes of the NMDA receptor activity measured at $-80 \mathrm{mV}$ and $-40 \mathrm{mV}$ are greatly reduced in $\mathrm{NR} 2 \mathrm{C}^{-1-}$ granule cells but are comparable between wild-type and $\mathrm{NR}_{2} \mathrm{~A}^{-1-}$ granule cells. Furthermore, the NMDA receptor activity of the NR2C ${ }^{-/-}$granule cells decays faster than that of the wild-type and $\mathrm{NR}_{2} \mathrm{~A}^{-1-}$ granule cells. Thus, the properties of the NMDA receptors in the NR2A ${ }^{-/-}$ and $\mathrm{NR} 2 \mathrm{C}^{-1-}$ granule cells most closely resemble those of recombinantly expressed NR1/NR2C and NR1/NR2A assemblies, respectively. Ebralidze et al. (1995) reported macroscopic and singlechannel recordings of NMDA receptor activities in cerebellar granule cells of the NR2C-deficient mice. They showed that the NR2C deficiency results in the disappearance of NMDA receptor channels of low unitary conductance that are normally expressed in granule cells during developmental maturation. Takahashi et al. (1995) reported single-channel recordings of NMDA receptormediated currents in cerebellar granule cells of the NR2A-deficient mice and indicated that NMDA receptor channels of low unitary conductance predominate in the NR2A-deficient granule cells. Ebralidze et al. (1995) also determined that the NMDA receptors in mature granule cells consist of the NR1/NR2A assembly with high conductance, the NR1/NR2C assembly with low conductance, and the NR1/NR2A/NR2C assembly in varying compositions with a wide range of conductance. In the present investigation, we have shown

that ablation of both NR2A and NR2C results in an almost complete loss of both spontaneous and evoked EPSCs in mature granule cells. Thus, these results demonstrate that both NR2A and NR2C subunits contribute to functional glutamatergic neurotransmission in mossy fiber-granule cell synapses of the mature cerebellum.

In the rat cerebellum, granule cells migrate from the external granular layer toward the internal granular layer during postnatal days 0-14 (Hager et al., 1995). The NMDA receptor has been reported to regulate the migration of granule cells in slice preparations of the developing mouse cerebellum; blockade of NMDA receptors by specific antagonists (D-AP5 or MK-801) and the stimulation of NMDA receptors decrease and increase the rate of cell movement, respectively (Komuro and Rakic, 1993). None of the three groups of mutant mice $\left(\mathrm{NR} 2 \mathrm{~A}^{-1-}, \mathrm{NR} 2 \mathrm{C}^{-1-}\right.$, and $\mathrm{NR} 2 \mathrm{~A}^{-/-} / \mathrm{NR} 2 \mathrm{C}^{-/-}$) show an overall morphological abnormality, including the cellular organization and the size and cell density of granule cells in the mature cerebellum. This finding in the $\mathrm{NR} 2 \mathrm{~A}^{-/-} / \mathrm{NR} 2 \mathrm{C}^{-/-}$mutant mice is particularly interesting because the NMDA receptor activity is negligible in these cells at postnatal days $18-20$. The NR2B mRNA is transiently expressed in granule cells during postnatal days 3-14 (Akazawa et al., 1994). Thus, our observation of the $\mathrm{NR} 2 \mathrm{~A}^{-1-} / \mathrm{NR} 2 \mathrm{C}^{-/-}$mutant mice supports the previous notion that the NR2A and NR2B subunits subserve different physiological requirements during cerebellar development, and the NR1/NR2B heteromeric receptor may have an active role in granule cell migration (Komuro and Rakic, 1993; Rossi and Slater, 1993; Farrant et al., 1994; Vallano et al., 1996).

Recently, three gene knockout mice that are relevant to cerebellar function in motor coordination have been generated and characterized (Aiba et al., 1994; Conquet et al., 1994; Chen et al., 1995; Kashiwabuchi et al., 1995). These are mice deficient in mGluR1, the glutamate receptor $\delta 2$ subunit (GluR $\delta 2)$, and $\operatorname{PKC} \gamma$, and these mutant mice show an ataxic gait (Aiba et al., 1994; Chen et al., 1995; Kashiwabuchi et al., 1995). The mGluR1 mutant mice also show intention tremor (Aiba et al., 1994; Conquet et al., 1994). In contrast, the $\mathrm{NR} 2 \mathrm{~A}^{-1-} / \mathrm{NR} 2 \mathrm{C}^{-1-}$ mutant mice never display ataxia or any sign of tremor and walk normally on the ground. Furthermore, in the rota-rod test, the mGluR1, GluR $\delta 2$, and PKC $\gamma$ mutant mice have been shown to fall off the slowly rolling rota-rod (8 or $10 \mathrm{rpm}$ ) (Aiba et al., 1994; Chen et al., 1995; Kashiwabuchi et al., 1995). In contrast, the $\mathrm{NR}_{2} \mathrm{~A}^{-1-} / \mathrm{NR} 2 \mathrm{C}^{-1-}$ mutant mice can manage to stay on the slowly running rota-rod $(10 \mathrm{rpm})$ and fail only the quickly running rota-rod $(25 \mathrm{rpm})$. The motor discoordination of the $\mathrm{NR}_{2} \mathrm{~A}^{-1-}$ / $\mathrm{NR} 2 \mathrm{C}^{-/-}$mutant mice is thus clearly milder than that of the mGluR1, GluR $\delta 2$, or PKC $\gamma$ knockout mice. It has been proposed that the NMDA receptors in cerebellar granule cells play an important role in determining the efficacy of synaptic summation and the output spike frequency in the mossy fiber-granule cell synapses during repetitive mossy fiber activation (D'Angelo et al., 1995). The NMDA receptors in granule cells could thus contribute to fine tuning the efficacy of information transmission at the mossy fiber-granule cell synapses and may influence its subsequent transfer to Purkinje cells (Larson-Prior et al., 1995). It is thus tempting to speculate that a loss of NMDA receptor activity in granule cells is directly involved in motor discoordination by impairing mossy fiber information processing.

\section{REFERENCES}

Aiba A, Kano M, Chen C, Stanton ME, Fox GD, Herrup K, Zwingman TA, Tonegawa S (1994) Deficient cerebellar long-term depression and impaired motor learning in mGluR1 mutant mice. Cell 79:377-388.

Akazawa C, Shigemoto R, Bessho Y, Nakanishi S, Mizuno N (1994)

Differential expression of five $N$-methyl-D-aspartate receptor subunit 
mRNAs in the cerebellum of developing and adult rats. J Comp Neurol 347:150-160.

Chazot PL, Coleman SK, Cik M, Stephenson FA (1994) Molecular characterization of $N$-methyl-D-aspartate receptors expressed in mammalian cells yields evidence for the coexistence of three subunit types within a discrete receptor molecule. J Biol Chem 269:24403-24409.

Chen C, Kano M, Abeliovich A, Chen L, Bao S, Kim JJ, Hashimoto K, Thompson RF, Tonegawa S (1995) Impaired motor coordination correlates with persistent multiple climbing fiber innervation in $\mathrm{PKC} \gamma$ mutant mice. Cell 83:1233-1242.

Conquet F, Bashir ZI, Davies CH, Daniel H, Ferraguti F, Bordi F, Franz-Bacon K, Reggiani A, Matarese V, Condé F, Collingridge GL, Crépel F (1994) Motor deficit and impairment of synaptic plasticity in mice lacking mGluR1. Nature 372:237-243.

D'Angelo E, Rossi P, Taglietti V (1993) Different proportions of $N$-methyl-D-aspartate and non- $N$-methyl-D-aspartate receptor currents at the mossy fibre-granule cell synapse of developing rat cerebellum. Neuroscience 53:121-130.

D'Angelo E, Rossi P, Taglietti V (1994) Voltage-dependent kinetics of $N$-methyl-D-aspartate synaptic currents in rat cerebellar granule cells. Eur J Neurosci 6:640-645.

D’Angelo E, De Filippi G, Rossi P, Taglietti V (1995) Synaptic excitation of individual rat cerebellar granule cells in situ: evidence for the role of NMDA receptors. J Physiol (Lond) 484:397-413.

Ebralidze AK, Rossi DJ, Tonegawa S, Slater NT (1995) The role of the NR2C subunit in NMDA receptor-gated channels in mouse cerebellar granule cells. Soc Neurosci Abstr 21:592.

Edwards FA, Konnerth A, Sakmann B, Takahashi T (1989) A thin slice preparation for patch clamp recordings from neurones of the mammalian central nervous system. Pflügers Arch 414:600-612.

Farrant M, Feldmeyer D, Takahashi T, Cull-Candy SG (1994) NMDAreceptor channel diversity in the developing cerebellum. Nature 368:335-339.

Hager G, Dodt HU, Zieglgänsberger W, Liesi P (1995) Novel forms of neuronal migration in the rat cerebellum. J Neurosci Res 40:207-219.

Hollmann M, Heinemann S (1994) Cloned glutamate receptors. Annu Rev Neurosci 17:31-108.

Ishii T, Moriyoshi K, Sugihara H, Sakurada K, Kadotani H, Yokoi M, Akazawa C, Shigemoto R, Mizuno N, Masu M, Nakanishi S (1993) Molecular characterization of the family of the $N$-methyl-D-aspartate receptor subunits. J Biol Chem 268:2836-2843.

Kashiwabuchi N, Ikeda K, Araki K, Hirano T, Shibuki K, Takayama C, Inoue Y, Kutsuwada T, Yagi T, Kang Y, Aizawa S, Mishina M (1995) Impairment of motor coordination, Purkinje cell synapse formation, and cerebellar long-term depression in GluR $\delta 2$ mutant mice. Cell 81:245-252.

Komuro H, Rakic P (1993) Modulation of neuronal migration by NMDA receptors. Science 260:95-97.

Kutsuwada T, Kashiwabuchi N, Mori H, Sakimura K, Kushiya E, Araki K, Meguro H, Masaki H, Kumanishi T, Arakawa M, Mishina M (1992) Molecular diversity of the NMDA receptor channel. Nature 358:36-41.

Larson-Prior LJ, Morrison PD, Bushey RM, Slater NT (1995) Frequency dependent activation of a slow $N$-methyl-D-aspartate-dependent excitatory postsynaptic potential in turtle cerebellum by mossy fibre afferents. Neuroscience 67:867-879.

Masu M, Iwakabe H, Tagawa Y, Miyoshi T, Yamashita M, Fukuda Y, Sasaki H, Hiroi K, Nakamura Y, Shigemoto R, Takada M, Nakamura
K, Nakao K, Katsuki M, Nakanishi S (1995) Specific deficit of the ON response in visual transmission by targeted disruption of the mGluR6 gene. Cell 80:757-765.

Mayer ML, Westbrook GL (1987) The physiology of excitatory amino acids in the vertebrate central nervous system. Prog Neurobiol 28:197-276.

Meguro H, Mori H, Araki K, Kushiya E, Kutsuwada T, Yamazaki M, Kumanishi T, Arakawa M, Sakimura K, Mishina M (1992) Functional characterization of a heteromeric NMDA receptor channel expressed from cloned cDNAs. Nature 357:70-74.

Monyer H, Sprengel R, Schoepfer R, Herb A, Higuchi M, Lomeli H, Burnashev N, Sakmann B, Seeburg PH (1992) Heteromeric NMDA receptors: molecular and functional distinction of subtypes. Science 256:1217-1221.

Moriyoshi K, Masu M, Ishii T, Shigemoto R, Mizuno N, Nakanishi S (1991) Molecular cloning and characterization of the rat NMDA receptor. Nature 354:31-37.

Nakanishi S (1992) Molecular diversity of glutamate receptors and implications for brain function. Science 258:597-603.

Nakanishi S, Masu M (1994) Molecular diversity and functions of glutamate receptors. Annu Rev Biophys Biomol Struct 23:319-348.

Pin JP, Duvoisin R (1995) The metabotropic glutamate receptors: structure and functions. Neuropharmacology 34:1-26.

Rabacchi S, Bailly Y, Delhaye-Bouchaud N, Mariani J (1992) Involvement of the $N$-methyl-D-aspartate (NMDA) receptor in synapse elimination during cerebellar development. Science 256:1823-1825.

Rossi DJ, Slater NT (1993) The developmental onset of NMDA receptor-channel activity during neuronal migration. Neuropharmacology 32:1239-1248.

Sakimura K, Kutsuwada T, Ito I, Manabe T, Takayama C, Kushiya E, Yagi T, Aizawa S, Inoue Y, Sugiyama H, Mishina M (1995) Reduced hippocampal LTP and spatial learning in mice lacking NMDA receptor $\epsilon 1$ subunit. Nature 373:151-155.

Silver RA, Traynelis SF, Cull-Candy SG (1992) Rapid-time-course miniature and evoked excitatory currents at cerebellar synapses in situ. Nature 355:163-166.

Streit P, Molnár E, Stierli B, Nusser Z, Lujan R, McIlhinney RAF, Somogyi P (1995) NMDA receptor subunit NR2A localized by monoclonal antibody. Soc Neurosci Abstr 21:85.

Takahashi T, Feldmeyer D, Suzuki N, Onodera K, Cull-Candy SG, Sakimura K, Mishina M (1995) Developmental changes in NMDA receptor channels in cerebellar granule cells. 4th IBRO World Congress Neurosci Abstr 16.

Vallano ML, Lambolez B, Audinat E, Rossier J (1996) Neuronal activity differentially regulates NMDA receptor subunit expression in cerebellar granule cells. J Neurosci 16:631-639.

van Riezen H, Boersma L (1969) A new method for quantitative grip strength evaluation. Eur J Pharmacol 6:353-356.

Watanabe M, Mishina M, Inoue Y (1994) Distinct spatiotemporal expressions of five NMDA receptor channel subunit mRNAs in the cerebellum. J Comp Neurol 343:513-519.

Wurst W, Joyner AL (1993) Production of targeted embryonic stem cell clones. In: Gene targeting, a practical approach (Joyner AL, ed), pp 33-61. Oxford: IRL. 